\title{
PHYSIOLOGICAL AND PRODUCTIVE IMPACTS OF BEAK TRIMMING AND FEED FORM IN JAPANESE QUAIL
}

\author{
M.G. Abdelfattah \\ Department of Poultry Production, Faculty of Agriculture, Assiut University, Assiut, Egypt, 71515 \\ Correspondence: Dr. MostafaGalalAbdelfattah, Department of Poultry Production, Assiut University, Assiut \\ (71516), Egypt. Tel: +20 01008133049; E-mail: moos311@yahoo.com\& $\underline{\text { mostafagalal@aun.edu.eg }}$
}

\section{SUMMARY}

A total number of 288 eight weeks old Japanese quail were chosen in this study for evaluating the impacts of beak trimming (BT) and feed physical forms $(F)$ on physiological, productive performance and aggressive behavior parameters, in a $2 \times 2$ factorial experimental design. The birds were allocated into two main groups according to beak form [Intact beak (NB) and beak trimming (BT)], then each main group was divided in to two subgroups corresponded to feed form [mash $(M)$ and pellet $(P)$ feed], respectively. The obtained results indicated that beak forms and feed forms significantly changed the final body weight, egg production, feed conversion, fertility \%, plumage conditions, aggressive pecking behavior, mortality rate, $\mathrm{H} / \mathrm{L}$ ratio, plasma testosterone, progesterone and corticosterone concentration. However, there were insignificant differences among the groups in feed intake, hatchability, ovary and testes percentages. Interactions between beak trimming and feed forms factors had significant differences in the plumage conditions, aggressive pecking behavior, mortality rate and hematological parameters. In conclusion: using the beak trimming did not have an adverse effect on quail ability of feeding (mash or pellet) and beak trimming was consider suitable solution to minimize aggressive behavior, mortality rates and maximize productive and reproductive performance of Japanese quail.

\section{Keywords: Beak trimming, feed form, egg production, hematological, aggressive behavior, quail}

\section{INTRODUCTION}

Despite of the undeniable technological advances achieved in the poultry industry, the domestication has not substantially altered the quail's aggressive behavior. Aggressive behavior is a serious problem faced the productivity of quail in the world and may lead to feathers picking, skin damage, cannibalism, which causes severe injuries even death and economic loss for producers of quails (Van Krimpenet al., 2005 and FAWC, 2007). The aggressive behavior of quail increased when sexual puberty is reached and during mating for competition male over females.

Beak trimming has become standard practice in the egg industry to reduce aggressive behavior but there is a global criticism to severe beak trimming of birds that is incompatible with bird welfare caused by chronic pain due to tissue damage and nerve injury, loss of normal function due to reduced ability to sense materials with the beak and loss of integrity of a living animal (Glatz, 2005; Glatz and Bourke, 2006;Kuenzel, 2007;CIVF, 2011 and Dennis and Cheng, 2012). In Egypt, the beak trimming is done as a last resort where alternatives are considered not to be acceptable or appropriate and was considered an appropriate economic solution and most efficient to minimize the risk of welfare problems caused by feather pecking, cannibalism, pain, injuries and social stress due to aggression behavior of the quails and thus reduce mortality (Cloutieret al., 2000 and Cheng, 2007). In addition, beak trimmed quails lower feed waste and improve productive performance (Oliveira, 2002).

The advantages of beak trimming are evident in mature birds, as reflected by reduced pecking damage and cannibalism and the increased production characteristics Glatz(2005). Severe beak trimming in laying quails may result in inadequate feed intake because the bird cannot easily pick up feed, especially small size (Campos, 1993 and Shunmuraet al., 2006). The moderate beak trimming in laying hens has only a short term effect on feed intake and performance traits. Successful quail production is dependent on optimal feed intake and feed efficiency (Martinecet al., 2002).

The physical form of feed (mash, pellet and crumble), feed particle size and the diet nutrient composition are considered the most a crucial factors to optimal feed intake and affect behavior and welfare of the birds ( Scott, 2002; Behnke and Beyer, 2004 and Amerahet al., 2007). The question is whether there has been adapted to feeding behavior with the new beak and what is the best form of feed (mash vs. pellet) with quail beak trimming that can yield high productivity performance remains unanswered.

Therefore, the objectives of present study were to investigate the effect of the beak trimming and feed physical form on aggression behavior, physiological and productive performance, especially the feed intake in its different forms (mash and pellet). 


\section{MATERIALS AND METHODS}

\section{Experimental design:}

This study was carried out at the poultry research farm of Poultry Production Department, Faculty of Agriculture, Assiut University, Assiut, Egypt. A total number of 288 eight weeks old, sexed Japanese quail birds were used in this study (in a $2 \times 2$ factorial experimental arrangement in a completely randomized design). The birds were wing banded, individually weighed (Initial weight) and randomly distributed into four equal groups each with six replicates of 12 birds (eight females + four males). The birds were allocated into two main groups according to beak form [Intact beak (NB) and beak trimming (BT)] and then, each main group was divided into two subgroups corresponded to feed physical form [mash (M) and pellet (P)] as shown in Table1. First group birds (G1) were kept without any beak trimming (non-beak trimming) with feeding mash, while second (G2) quails were non-beak trimming with feeding pellets diet. The third group (G3) birds were beak trimmed (debeaked) with feeding mash while, fourth group (G4) were beak trimmed and feeding pellets diet. The beak trimming process was practised at 15 days of age and retrimmed at 56 days of age. Beak trimming was conducted according to industry standards for beak trimmer accreditation (Bourke et al., 2002).Beak trimming (BT) treatments were applied using a hot blade Lyon Debeaker ${ }^{\circledR}$ (Lyon Electric Company, Inc., Chula Vista, CA, USA), cut one-third length the upper and lower beak and wound was cauterized for two seconds (Glatz, 2005).At six weeks birds was housed in production pens for two weeks for the purpose of acclimatization. At eight week of age, all groups were distributed into 24 breeding housing pens from galvanized iron mesh with dimensions (57 length $\times 50$ width $\times 30$ height $\mathrm{cm}$ ), 12 birds/pen (8females +4 males), with sex ratio 2:1. Each pen was equipped with automatic nipple drinkers, and feed was provided via trough feederswhich located at the pen front. All birds were raised under standard environmental and hygienic conditions. Vaccination and medical programmes were performed according to the different stages of age under supervision of a licensed veterinarian.

Table1.Groups description

\begin{tabular}{ccc}
\hline Groups & Beak form (B) & Feed form (F) \\
\hline G1 & Intact beak (NB) & Mash (M) \\
G2 & Intact beak (NB) & Pellets (P) \\
G3 & Beak Trimming(BT) & Mash (M) \\
G4 & Beak Trimming(BT) & Pellets (P) \\
\hline
\end{tabular}

\section{Environmental conditions:}

The newly hatched quail chicks were kept under similar recommended hygienic management conditions in brooding floor pens until they were 6 weeks of age and then transferred to the breeding house. Lighting program was 23 hours light:1hour dark during the first 3 days, which was gradually decreased (one $\mathrm{hr} /$ week) to reach 16 hours light/day at 8 weeks of age and this regime was lasted constant till the end of the study (20 weeks of age). An automatic clock was used to control light period during the entire experiment. Light intensity during rearing period was 50 lux and 40-50 lux during study period at the head of birds as measured by luxmeter. Temperature and relative humidity were daily recorded during the experimental period by using thermometer and hygrometer located in the central part of the house. The quail chicks' brood room temperature was gradually decreased from $35-37^{\circ} \mathrm{C}$ at hatching to $20-23^{\circ} \mathrm{C}$ at five weeks of age and relative humidity average was $60-65 \%$ up to the end experiment. Water and feed were continuously provided during the study period. The Birds were fed mash and pellets diet based on corn and soybean meal, and formulated to meet the nutritional requirements of quail birds according to the (NRC, 1994) recommendations. The rations contained $24 \%$ crude protein (CP) and $2800 \mathrm{ME} \quad \mathrm{Kcal} / \mathrm{kg}$ metabolizable energy (growing period) and 20\% (CP) (laying period) with $3000 \mathrm{Kcl}(\mathrm{ME}) / \mathrm{Kg}$.

\section{Studied traits: \\ Body weight and egg production:}

The initial and final body weights (BW, g) were recorded at 8 and 20 weeks of age, respectively. Overall means of feed intake (FI, g/day) and feed conversion ratio as (FCR, $g$ feed: $g$ egg) were calculated during egg production period. The age at $50 \%$ production was accepted as the beginning of collected egg production data, as described previously (North and Bell, 1990). Eggs from each replicate were daily collected, counted and weighed to evaluate average eggs laying rate (ELR \%) and egg weight (EW, g) while, egg mass (EM, g egg/hen/day). At 20 weeks of age the cloacal gland areas dimensions (height and width per $\mathrm{mm}$ ) were measured for males by using a caliper. Mortality attributable to cannibalism and other death causes were recorded daily and expressed as percentage throughout the experimental period.

\section{Egg quality parameters:}

One hundred and twenty fresh eggs (30 eggs /group) were used to evaluate the external and internal egg quality parameters on $12^{\text {th }}$ week of age corresponding to the maximum production peak. Eggs were identified according to treatment, and individually weighed in 0.01 precision digital scales. Egg long and short axes were determined by caliper to calculated egg shape index. Internal eggs quality was assessed by measuring albumen, yolk height and 
yolk diameter along the chalazae line by using the caliper $(\mathrm{mm})$. Thereafter, yolk was separated and weighted, also eggshell was dried and weighted and then the albumen was calculated by differences to the nearest 0.5 gram. Shell thickness was measured by using eggshell micrometer a Mituyoto caliper, with sensitivity to 0.01 as described by (Souza et al., 1984).Haugh unit, shape index (\%), yolk index (\%) and shell percentage (\%) were estimated by following equationsaccording to (Carter 1975 and Kul and Seker, 2004).

Shape index $(\%)=[$ egg width $(\mathrm{cm}) /$ egg height $(\mathrm{cm})] \times 100$

Yolk index (\%) [Yolk height / yolk diameter)] $\times 100$

Shell percentage $(\%)=[$ Shell weight $(\mathrm{g}) /$ Egg weight $(\mathrm{g})] \times 100$.

Haugh unit $(\mathrm{HU})=100 \times \log ($ Thick albumen height -1.7 egg weight $\left.{ }^{0.37}+7.6\right)$

\section{Incubation traits:}

A total of 6600 eggs were used to determine fertility and hatchability percentages from all experimental groups throughout the experimental period. Eggs laid were collected daily for 5 successive days and stored at $18 \mathrm{C}^{\circ}$ and $65 \%$ relative humidity before placed it in the incubator from each group. The incubator conditions were $37.8 \mathrm{C}^{\circ}$ with $55-60 \%$ relative humidity up to 14 days of incubation period, while the relative humidity from 15-17days of incubation was 60 to $65 \%$. At hatching, all live and dead chicks were counted while, the un-hatched eggs were opened and classified to eggs with embryonic development were considered fertile, while the remainder eggs were considered infertile according to (Khalil, 2009).

Fertility $(\%)=($ fertile eggs number $) \times 100 /$ (total incubated eggs).

Hatchability of fertile eggs $(\%)=$ (chicks hatched number) $\times 100 /$ (fertile eggs number).

Embryonic mortality $(\%)=($ dead embryos number $)$ $\times 100 /$ (total incubated eggs).

\section{Feather score:}

Feather score was used to visually assess the quality of feather coverage and feather pecking degree of each bird at 20 weeks of age. The feather scoring system of five body regions on the bird (neck, back, rump, wing and tail) were assessed using the method described by (Tausonet al., 1984, 2005 and Bright et al. 2006) as shown in Table 2. This method gives feather score of 1 to 5 , with 1 being the best condition (good full feathering and no damage) and 5 the worst plumage condition (severe feathers damage, large bare spots, broken skin, bloody or wounded areas) (Dennis et al., 2009). Feather scores were averaged to give a mean feather score for each body region and the total average feather score for five areas was calculated with values ranging from 5 (completely feathered) to 25 points (featherless) according to (Gerken, 1991, Tausonet al., 2005 and Khalil et al., 2011, 2012 and 2015).

Table 2. Feather damage score

\begin{tabular}{|c|c|}
\hline Score & Score Description \\
\hline 1 & Smooth, complete plumage with no or little damage \\
\hline 2 & $\begin{array}{l}\text { Slight damage to any area of the body with feathers ruffled, body completely or almost } \\
\text { completely covered }\end{array}$ \\
\hline 3 & Sever damage to feathers and small bare spots \\
\hline 4 & Sever damage to feathers and large bare spots \\
\hline 5 & Sever damage to feathers, area completely bare with injury to skin or broken skin \\
\hline
\end{tabular}

Aggressive pecking behavior:

Aggressive pecking behavior was defined as bleeding injuries, as a result of pecking by other birds. Aggressive pecking behaviors were visually evaluated as follows: head injures score from 1 (intact head) to 5 (injured head). Eyelid injuries score were assessed using a scale from 1 (intact eyelid) to 5 (all eyelid injuries), two eyelids injuries 2 to 10 ). Eye closed score $(1$ or 2$), 1=$ open eye, $2=$ closed eye, two eyes closed score (from 2 to 4 ). Eye lost score (1 or 2 ), $1=$ present eye, $2=$ absent eye, two eyes lost score (from 2 to 4) according to (Khalil et al. (2015).

\section{Blood constituents:}

At 20 weeks of age, six random birds from each groups were slaughtered, weighed and scarified by severing the jugular vein and blood was allowed to flow freely into labeled bottle contained a speck of EDTA. Non-coagulated blood was tested shortly after collection for the count of red blood cells (RBCs, $10^{6}$ ), white blood cells (WBCs, 10 ${ }^{3}$ ), differential count of WBC's subclasses (lymphocyte, heterophils, monocytes, eosinophils, and basophils percentages), hemoglobin $(\mathrm{Hb}, \mathrm{g} / \mathrm{dl})$ concentration and packed cell volume (PCV \%) according to (Drew et al., 2004). Therefore, blood plasma were separated by centrifugation at $3000 \mathrm{rpm}$ for 15 minutes and stored at $\left(-20^{\circ} \mathrm{C}\right)$ for further analysis. The plasma sex hormones (testosterone and progesterone) and corticosterone hormones were determined according to the manufacture recommendations of commercial kits.

\section{Genital organs of female and male quails:}

Testis, ovaries, ovarian yellow follicles percentages and numbers were also estimated, left and right testis dimensions and oviducts lengths were recorded.

\section{Statistical analysis:}

Data were analyzed using a two way analysis of variance (ANOVA)with beak trimming and feed form effects by applying the general linear model procedure to analyze the differences between treatment groups using SAS software (SAS Institute, version 9.2, 2009). Duncan's multiple range test 
(Duncan, 1955) was used to detect differences among means of different groups. All values expressed in percentages were transformed to arcsine before analysis, according to (Steel and Torrie, 1980).

Statisticalmodel: $\mathrm{Y}_{\mathrm{ijk}}=\mu+\mathrm{B}_{\mathrm{i}}+\mathrm{F}_{\mathrm{j}}+\mathrm{BF}_{\mathrm{ij}}+\mathrm{E}_{\mathrm{ijK}}$

Where: $Y_{i k}=$ observed value of the concerned trait. $\mu$ $=$ observed mean for the concerned trait.

$B_{i}=$ the fixed effect due to beak trimming $(i=1,2) F_{j}$ $=$ the fixed effect due to feed form $(j=1,2)$

$\mathrm{BF}_{\mathrm{ij}}=$ the fixed effect due to beak form and feed form. $\mathrm{E}_{\mathrm{ijk}}=$ the random errors.

\section{RESULTS AND DISCUSSION}

\section{Body weight:}

Although the initial body weight of the birds did not significantly differ, the results indicated that the
BT birds had significantly heavier final body weight than the NB groups (Table 3). Initial and final body weights of birds fed mash and pellets groups showed no differences. These results were supported by Farghly (2012) who reported no differences in body weight and gain due to feed forms. In contrast to the present results, Preston et al. (2000) reported that birds fed pellets had better growth performances than those fed mash form. Feed physical form may contribute to improve the growth performance of chicken by effects on physiological functions of the digestive tract and enhanced protein efficiency (Greenwood et al., 2004 and Lvet al., 2015). There were no interactions between beak form andfeed physical form on initial and final body weights.

Table 3. Effect of beak trimming (BT) and feed form (F) on productive traits in Japanese quail

\begin{tabular}{|c|c|c|c|c|c|c|c|c|c|}
\hline \multirow{2}{*}{$\begin{array}{c}\text { Traits } \rightarrow \\
\text { Treatment } \downarrow\end{array}$} & \multicolumn{2}{|c|}{$\begin{array}{c}\text { Female body weight } \\
\text { (g) }\end{array}$} & \multicolumn{2}{|c|}{$\begin{array}{l}\text { Male body weight } \\
\text { (g) }\end{array}$} & \multicolumn{5}{|c|}{ Egg production } \\
\hline & Initial & Final & Initial & Final & $\begin{array}{c}\text { ELR } \\
(\%)\end{array}$ & $\begin{array}{c}\mathbf{E W} \\
(\mathrm{g})\end{array}$ & $\begin{array}{c}\text { EM } \\
(\mathrm{g} \\
\mathrm{egg} / \mathrm{hen} / \mathrm{d}) \\
\end{array}$ & $\begin{array}{c}\text { FI } \\
(\mathrm{g} / \mathrm{d})\end{array}$ & $\begin{array}{c}\text { FCR } \\
\text { (g feed: } \\
\text { g egg) }\end{array}$ \\
\hline \multicolumn{10}{|c|}{ Beak form (B) } \\
\hline $\begin{array}{l}\text { Beak trimming } \\
\text { (BT) }\end{array}$ & $269.61^{\mathrm{a}}$ & $273.01^{\mathrm{a}}$ & $254.89^{\mathrm{a}}$ & $240.62^{\mathrm{a}}$ & $75.39^{\mathrm{a}}$ & $12.27^{\mathrm{a}}$ & $9.25^{\mathrm{a}}$ & $31.93^{\mathrm{b}}$ & $2.60^{\mathrm{b}}$ \\
\hline $\begin{array}{l}\text { Intact beak } \\
\text { (NB) }\end{array}$ & $271.38^{\mathrm{a}}$ & $259.82^{\mathrm{b}}$ & $254.62^{\mathrm{a}}$ & $231.7^{b}$ & $67.36^{\mathrm{b}}$ & $12.15^{\mathrm{a}}$ & $8.19^{b}$ & $37.41^{\mathrm{a}}$ & $3.10^{\mathrm{a}}$ \\
\hline SEM & 1.25 & 1.62 & 2.27 & 1.598 & 1.02 & 0.06 & 014 & 0.56 & 0.04 \\
\hline Significance & 0.32 & $<.0001$ & 0.93 & 0.0002 & $<.0001$ & 01.94 & $<.0001$ & $<.0001$ & $<.0001$ \\
\hline \multicolumn{10}{|c|}{ Feed form (F) } \\
\hline $\operatorname{Mash}(\mathrm{M})$ & $269.92^{\mathrm{a}}$ & $268.26^{\mathrm{a}}$ & $255.75^{\mathrm{a}}$ & $235.67^{\mathrm{a}}$ & $69.81^{b}$ & $12.15^{\mathrm{a}}$ & $8.49^{\mathrm{b}}$ & $35.37^{\mathrm{a}}$ & $2.92^{\mathrm{a}}$ \\
\hline Pellets (P) & $271.07^{\mathrm{a}}$ & $264.56^{\mathrm{a}}$ & $253.76^{\mathrm{a}}$ & $236.66^{\mathrm{a}}$ & $72.94^{\mathrm{a}}$ & $12.27^{\mathrm{a}}$ & $8.95^{\mathrm{a}}$ & $33.95^{\mathrm{a}}$ & $2.78^{\mathrm{b}}$ \\
\hline SEM & 1.25 & 1.62 & 2.27 & 1.598 & 1.02 & 0.06 & 0.14 & 0.56 & 0.04 \\
\hline Significance & 0.51 & 0.11 & 0.54 & 0.66 & 0.05 & 0.22 & 0.03 & 0.10 & 0.03 \\
\hline \multicolumn{10}{|c|}{ Interaction $(\mathbf{B} \times \mathbf{F})$} \\
\hline $\mathbf{B T} \times \mathbf{M}$ & 269.88 & 276.84 & 255.31 & 242.11 & 74.30 & 12.18 & 9.04 & 32.23 & 2.64 \\
\hline $\mathbf{B T} \times \mathbf{P}$ & 269.36 & 268.18 & 254.47 & 239.14 & 76.48 & 12.36 & 9.45 & 31.62 & 2.56 \\
\hline $\mathbf{N B} \times \mathbf{M}$ & 269.97 & 259.69 & 256.19 & 229.25 & 65.32 & 12.12 & 7.93 & 38.51 & 3.20 \\
\hline $\mathbf{N B} \times \mathbf{P}$ & 272.80 & 259.96 & 253.06 & 234.18 & 69.40 & 12.18 & 8.46 & 36.30 & 3.00 \\
\hline SEM & 1.77 & 2.29 & 3.21 & 2.26 & 1.11 & 0.09 & 0.20 & 0.80 & 0.06 \\
\hline Significance & 0.34 & 0.09 & 0.72 & 0.08 & 0.52 & 0.52 & 0.76 & 0.33 & 0.35 \\
\hline
\end{tabular}

Means within each column for each division with no common superscript letters are significantly different $(p \leq .05)$.

Egg production traits:

Regarding egg production traits, the egg laying rate $(\%)$ of the trimmed bids was significantly superior over the (NB) groups. However, no significance differences were observed between (BT) and (NB) groups in egg weight during egg production period. The improved body weight and egg production traits for (BT) birds groups may be due to the improved feed conversion ratio in birds submitted to mild beak trimming, since they cannot choose ingredients in the feed, thereby preventing loss of feed (Pizzolanteet al., 2007). In addition, this improvement in the production of eggs can be associated with changes in the levels of the adrenal and reproductive hormones. Also, this may be due to a lower incidence of pecked eggs due to less aggressive behavior, lower peaking feather incidence and lower mortality rate.
The increased egg mass for quails in the (BT) groups could be attributed to improving feed intake, feed conversion and egg number as compared with the quails with (NB) groups. Quails fed pelleted feed produced more eggs and eggs mass as compared to those fed mash. The current results agree with the findings of Murakami et al. (2008) and Farghly (2012) who reported that the egg production and egg mass of pellets groups significantly $(\mathrm{P} \leq 0.05)$ exceeded than of mash groups. The improved egg production obtained with pelleted feed may be attributed to improved diet digestibility caused by the process of pelletization, which changes the diet structure of proteins, favoring their digestion, and increasing amino acid availability for egg production (Frikha, et al., 2009). Moreover, there was no difference between beak form and feed form interaction in all egg production traits. 
Feed Intake (FI) and feed conversion (FCR):

The trimmed birds clearly consumed less feed than the (NB) group which resulted in improving (FCR). The reduction feeding ability after beak trimmed in the quails may be due to recurring pain at the trimming site and reduced birds' mechanical ability and desire to pick up food (GLATZ, 1987).In addition, the higher (FI) by the (NB) birds could have been caused by the combination of a higher metabolic energy requirement, as a result of more body movement and of the feather condition deteriorated (Mertenset al., 2009). The improvement in the (FCR) of (BT) birds is agreed with those of (Marchant-Forde and Cheng, 2010), who stated that the (BT) improved (FCR) due to less feed waste. Conversely, (Leandro et al., 2005) found worse feed (FCR) in quails submitted to $1 / 3$ and $2 / 3$ trimming and cauterization of the beak than that of the (NB) birds. Similarly, Maizama and Adams, (1994) reported that FCR was better in layers (NB) groups than trimmed groups during the period from 20 to 40 week of age. The feed Intake was insignificantly affected by feed form these results may be due to low quality of pellets (Moran, 1990). These results are consistent with those of (Farghly, 2012) who found that feed form had no effect on birds (FI). In contrast, to our results, (Rajput et al., 2016) was reported that the (FI) of Japanese quail fed on mash feed was higher than fed on pellet feed.

In the present study, birds fed pellets had better (FCR) than those fed mash feed. The superiority of birds fed pellet feed may be attributed to the improved nutritive value of pellet through increased feed flow ability, nutritional physical density, an enhancement of feed palatability, appetite and promoting nutrient digestibility. The improves nutrient utilization of thepellet resulting from chemical action during pellet thermo-mechanical process, processing increased nutrient digestibility also, pelleted feeds had less feed wastage (Dozier et al., 2010 and Moritz et al., 2005). In addition, pellets particles with suitable dimension for the oral cavity of the bird require less physical efforts to ingest them with allowed a reduction in the energy for food and, therefore, a higher net energy (NE) value. (Cerrateet al., 2009 and Mingbin, 2015). Otherwise Mash feed tends to stick to the inside of the birds beak, resulting in a fall in food intake and consequently reduced performance (McDonald, 1987). furthermore, feeding pellets uniform feed particle improves (FCR) by prevents birds to choose feeds particle as pelleting promotes better aggregation of the diet components, avoiding nutrient imbalance and feedstuff segregation during feed transportation and handling (López and Baião, 2004). However, interaction of (B $\mathrm{x} F$ ) showed insignificant effects on (FC) and (FCR) values.These results agree withTanaka et al., (1983) who examined the effect of (BT) and feed form (pellet and mash), and reported that the time spent eating was shorter in cages with mashed food, though feed intake did not change. Therefore, before beak trimming, it may be difficult for laying hens to maintain feeding for a long time because aggression occurred frequently, resulting in a high frequency of birds eating and feed wastage. Hence, aggression decreased after beak trimming, resulting in a decreasing proportion of birds eating. The feeding behavior had an impact on amount of waste feed which was associated with the anatomy of the beak (Adeola, 2006).

\section{Egg quality traits:}

Egg quality results are displayed in Table 4. It could be noted that the egg shape index, egg shell thickness and shell percentages for quails were not affected by the (BT). Similar results were obtained by EbruOnbaşılaret al. (2009) who found that the egg weight and shape index for eggs produced from laying hens were insignificantly affected in the (NT) groups, a trim at one day, 10 days and 10 weeks of age. However, the higher values of yolk index, albumen percentage and Haugh unit were recorded in eggs laid from (NB) groups compared to record from the (BT) groups Table 4. The yolk percentage of eggs produced from quails in (BT) groups significantly $(\mathrm{P} \leq 0.05)$ increased than of the $(\mathrm{NB})$ groups. These findings agree with those of (Hassanien and AbdelWareth, 2012), who found that the percentage of yolk was significantly higher in the trimming hens in the treated groups. Referring to feed physical form effect the results showed that the birds feed pellets diet had higher egg shape index, shell percentages and Haugh unit than of the quails fed mash diet. These results are consistent with those of (Farghly, 2012) who reported the results showed that treatments birds fed pellets and wet diets had superior shell thickness, Haugh units compared with mash feed. Moreover, there were no significant interactions between (BT) and feed form in all egg quality traits except egg shell index and shell percentages.

\section{Feather score:}

The feather scores of each part of the body are shown in Tables 5 and 6 . The present results indicate that the plumage deterioration was significantly reduced by beak trimming because aggression decreased and the force of pecking was weakened by the beak trimming compared to (NB). These results sre in agreement with (Mertenset al., 2009). Based on the results, more feather damage was observed in the neck and back than to other regions of the body in all groups. Also, the best plumage quality of the body in each group was measured for the tail and wing region. The neck and back areas pecked frequently resulted in more feather damage than other regions of the body in all groups. Generally, the results show that the areas of the body that are constantly exposed to feather aggressive pecking are related to the feather structure as well as the parts that can be touched during male mating, namely neck and back and aggressive behavior was prevented by beak trimming (Mertenset al., 2009). The plumage deterioration in quails with (NB) groups could be attributed to pecking the feathers during mating in the cage, leading to loss of feathers in the dorsal region, 
which may impair thermal regulation processes (Pizzolanteet al., 2007). Data presented in Tables 5 and 6, show insignificant differences $(\mathrm{P}>0.05)$ in total feather score between the experimental four groups for males and females as affected by the feed physical form. These results are in agreement with Farghly and Abou-Kassem (2014) and Farghlyet al. (2014) who reported insignificant differences in plumage conditions between birds fed mash and pellets diet. The physical form of the diet and the distribution of particle size in mash diets can affect feather pecking behavior, possibly due to differences in time spending on feed intake (Walser and Pfirter, 2001). Interaction $B \times F$ did not have any effect on total feather score of females. However, it can also be derived that the males beak trimmed were fed mash diet had a better plumage score than groups with (NB) fed pellets diet.

Table4. Effect of beak trimming (BT) and feed form on egg quality traits in Japanese quail

\begin{tabular}{|c|c|c|c|c|c|c|c|}
\hline $\begin{array}{c}\text { Traits } \rightarrow \\
\text { Treatment } \downarrow\end{array}$ & $\begin{array}{c}\text { Shape index } \\
(\%)\end{array}$ & $\begin{array}{l}\text { Yolk index } \\
(\%)\end{array}$ & $\begin{array}{l}\text { Haugh } \\
\text { units }\end{array}$ & $\begin{array}{l}\text { Shell thickness } \\
\text { (mm) }\end{array}$ & Yolk\% & $\begin{array}{c}\text { Albumen } \\
\text { (\%) }\end{array}$ & $\begin{array}{l}\text { Shell } \\
(\%)\end{array}$ \\
\hline \multicolumn{8}{|c|}{ Beak form (B) } \\
\hline Beak trimming (BT) & $78.50^{\mathrm{a}}$ & $45.34^{\mathrm{b}}$ & $88.63^{b}$ & $22.5^{\mathrm{a}}$ & $32.18^{\mathrm{a}}$ & $58.75^{\mathrm{b}}$ & $9.07^{\mathrm{a}}$ \\
\hline Intact beak (NB) & $79.72^{\mathrm{a}}$ & $47.14^{\mathrm{a}}$ & $91.98^{\mathrm{a}}$ & $22.38^{\mathrm{a}}$ & $31.52^{\mathrm{b}}$ & $59.51^{\mathrm{a}}$ & $8.97^{\mathrm{a}}$ \\
\hline SEM & 0.81 & 0.25 & 0.39 & 0.20 & 0.12 & 0.217 & 0.07 \\
\hline Significance & 0.29 & 0.004 & $<.0001$ & 0.66 & 0.02 & 0.01 & 0.31 \\
\hline \multicolumn{8}{|c|}{ Feed form $(\mathrm{F})$} \\
\hline Mash (M) & $77.83^{b}$ & $46.32^{\mathrm{a}}$ & $89.49^{b}$ & $22.28^{\mathrm{a}}$ & $31.85^{\mathrm{a}}$ & $59.23^{\mathrm{a}}$ & $8.92^{\mathrm{b}}$ \\
\hline Pellets (P) & $80.39^{\mathrm{a}}$ & $46.15^{\mathrm{a}}$ & $91.13^{\mathrm{a}}$ & $22.60^{\mathrm{a}}$ & $31.86^{\mathrm{a}}$ & $59.03^{\mathrm{a}}$ & $9.12^{\mathrm{a}}$ \\
\hline SEM & 0.81 & 0.25 & 0.39 & 0.20 & 0.12 & 0.21 & 0.07 \\
\hline Significance & 0.003 & 0.76 & 0.04 & 0.26 & 0.99 & 0.51 & 0.05 \\
\hline \multicolumn{8}{|c|}{ Interaction $(\mathrm{B} \times \mathrm{F})$} \\
\hline $\mathrm{BT} \times \mathrm{M}$ & 77.30 & $46.22^{\mathrm{a}}$ & 88.02 & 22.60 & 32.18 & 50.04 & $9.13^{\mathrm{a}}$ \\
\hline $\mathrm{BT} \times \mathrm{P}$ & 79.71 & $44.46^{\mathrm{b}}$ & 89.24 & 22.40 & 32.18 & 58.80 & $9.02^{\mathrm{a}}$ \\
\hline $\mathrm{NB} \times \mathrm{M}$ & 78.36 & $46.43^{\mathrm{a}}$ & 90.95 & 21.95 & 31.52 & 59.76 & $8.72^{\mathrm{b}}$ \\
\hline $\mathrm{NB} \times \mathrm{P}$ & 81.08 & $47.84^{\mathrm{a}}$ & 93.02 & 22.80 & 31.52 & 59.26 & $9.22^{\mathrm{a}}$ \\
\hline SEM & 0.54 & 0.35 & 0.56 & 0.288 & 0.17 & 0.179 & 0.100 \\
\hline Significance & 0.40 & 0.01 & 0.45 & 0.07 & 0.98 & 0.32 & 0.003 \\
\hline
\end{tabular}

Means within each column for each division with no common superscript letters are significantly different $(p \leq .05)$.

Table5. Effect of beak trimming and feed form on plumage conditions score for body regions of the female quail

\begin{tabular}{|c|c|c|c|c|c|c|}
\hline $\begin{array}{c}\text { Traits } \rightarrow \\
\text { Treatment } \downarrow\end{array}$ & Neck & Back & Rump & Tail & wing & Total \\
\hline \multicolumn{7}{|c|}{ Beak form (B) } \\
\hline Beak trimming (BT) & $1.52^{\mathrm{b}}$ & $1.56^{\mathrm{b}}$ & $1.39^{\mathrm{b}}$ & $1.47^{\mathrm{b}}$ & $1.53^{\mathrm{b}}$ & $7.47^{\mathrm{b}}$ \\
\hline Intact beak (NB) & $3.28^{\mathrm{a}}$ & $3.25^{\mathrm{a}}$ & $2.94^{\mathrm{a}}$ & $2.95^{\mathrm{a}}$ & $2.88^{\mathrm{a}}$ & $15.30^{\mathrm{a}}$ \\
\hline SEM & 0.08 & 0.08 & 0.07 & 0.77 & 0.084 & 0.31 \\
\hline Significance & $<.0001$ & $<.0001$ & $<.0001$ & $<.0001$ & $<.0001$ & $<.0001$ \\
\hline \multicolumn{7}{|c|}{ Feed form $(\mathrm{F})$} \\
\hline $\operatorname{Mash}(\mathrm{M})$ & $2.45^{\mathrm{a}}$ & $2.41^{\mathrm{a}}$ & $2.03^{\mathrm{b}}$ & $2.10^{\mathrm{b}}$ & $2.14^{\mathrm{a}}$ & $11.13^{\mathrm{a}}$ \\
\hline Pellets $(\mathrm{P})$ & $2.35^{\mathrm{a}}$ & $2.40^{\mathrm{a}}$ & $2.30^{\mathrm{a}}$ & $2.32^{\mathrm{a}}$ & $2.27^{\mathrm{a}}$ & $11.64^{\mathrm{a}}$ \\
\hline SEM & 0.08 & 0.08 & 0.07 & 0.077 & 0.084 & 0.31 \\
\hline Significance & 0.38 & 0.93 & 0.01 & 0.05 & 0.28 & 0.25 \\
\hline \multicolumn{7}{|c|}{ Interaction $(B \times F)$} \\
\hline $\mathrm{BT} \times \mathrm{M}$ & $1.34^{\mathrm{d}}$ & $1.44^{\mathrm{c}}$ & 1.32 & 1.46 & 1.54 & 7.10 \\
\hline $\mathrm{BT} \times \mathrm{P}$ & $1.70^{\mathrm{c}}$ & $1.68^{\mathrm{b}}$ & 1.46 & 1.48 & 1.52 & 7.84 \\
\hline $\mathrm{NB} \times \mathrm{M}$ & $3.56^{\mathrm{a}}$ & $3.38^{\mathrm{a}}$ & 2.74 & 2.75 & 2.73 & 15.16 \\
\hline $\mathrm{NB} \times \mathrm{P}$ & $3.00^{\mathrm{b}}$ & $3.12^{\mathrm{a}}$ & 3.14 & 3.16 & 3.02 & 15.44 \\
\hline SEM & 0.11 & 0.11 & 0.11 & 0.11 & 0.12 & 0.44 \\
\hline Significance & $<.0001$ & 0.03 & 0.23 & 0.07 & 0.21 & 0.61 \\
\hline
\end{tabular}

Means within each column for each division with no common superscript letters are significantly different $(p \leq .05)$.

Table6. Effect of beak trimming and feed form on plumage conditions score for body regions of the male quail

\begin{tabular}{|c|c|c|c|c|c|c|}
\hline $\begin{array}{c}\text { Traits } \rightarrow \\
\text { Treatment } \downarrow\end{array}$ & Neck & Back & Rump & Tail & wing & Total \\
\hline \multicolumn{7}{|c|}{ Beak form (B) } \\
\hline Beak trimming (BT) & $1.66^{\mathrm{b}}$ & $1.50^{\mathrm{b}}$ & $1.46^{\mathrm{b}}$ & $1.42^{\mathrm{b}}$ & $1.46^{\mathrm{b}}$ & $7.50^{\mathrm{b}}$ \\
\hline Intact beak (NB) & $3.08^{\mathrm{a}}$ & $2.9^{\mathrm{a}}$ & $2.92^{\mathrm{a}}$ & $2.86^{\mathrm{a}}$ & $2.86^{\mathrm{a}}$ & $14.68^{\mathrm{a}}$ \\
\hline SEM & 0.14 & 0.146 & 0.141 & 0.145 & 0.143 & 0.67 \\
\hline Significance & $<.0001$ & $<.0001$ & $<.0001$ & $<.0001$ & $<.0001$ & $<.0001$ \\
\hline \multicolumn{7}{|c|}{ Feed form $(F)$} \\
\hline Mash (M) & $2.28^{\mathrm{a}}$ & $2.14^{\mathrm{a}}$ & $2.12^{\mathrm{a}}$ & $2.08^{\mathrm{a}}$ & $2.08^{\mathrm{a}}$ & $10.70^{\mathrm{a}}$ \\
\hline Pellets $(\mathrm{P})$ & $2.46^{\mathrm{a}}$ & $2.32^{\mathrm{a}}$ & $2.26^{\mathrm{a}}$ & $2.20^{\mathrm{a}}$ & $2.24^{\mathrm{a}}$ & $11.48^{\mathrm{a}}$ \\
\hline SEM & 0.145 & 0.146 & 0.141 & 0.145 & 0.143 & 0.671 \\
\hline Significance & 0.38 & 0.386 & 0.48 & 0.56 & 0.43 & 0.41 \\
\hline \multicolumn{7}{|c|}{ Interaction $(B \times F)$} \\
\hline $\mathrm{BT} \times \mathrm{M}$ & 1.40 & $1.20^{\mathrm{d}}$ & $1.16^{\mathrm{d}}$ & 1.16 & $1.16^{\mathrm{d}}$ & $6.08^{d}$ \\
\hline $\mathrm{BT} \times \mathrm{P}$ & 1.92 & $1.80^{\mathrm{c}}$ & $1.76^{\mathrm{c}}$ & 1.68 & $1.76^{\mathrm{c}}$ & $8.92^{\mathrm{c}}$ \\
\hline $\mathrm{NB} \times \mathrm{M}$ & 3.16 & $3.08^{\mathrm{a}}$ & $3.08^{\mathrm{a}}$ & 3 & $3^{\mathrm{a}}$ & $14.04^{\mathrm{b}}$ \\
\hline $\mathrm{NB} \times \mathrm{P}$ & 3.00 & $2.84^{\mathrm{b}}$ & $2.76 \mathrm{~b}$ & 2.72 & $2.71^{\mathrm{b}}$ & $15.32^{\mathrm{a}}$ \\
\hline SEM & 0.20 & 0.21 & 0.20 & 0.21 & 0.20 & 0.95 \\
\hline Significance & 0.10 & 0.05 & 0.02 & 0.06 & 0.03 & 0.03 \\
\hline
\end{tabular}




\section{Aggressive pecking behavior}

Aggressive pecking behavior among Japanese quail males as affected by beak form are shown in Table 7. The lowest value of head injuries was recorded in (BT) males compared to (NB) groups. Also, the males with (NB) had significantly higher eyelids injuries than (BT) groups. Moreover, the higher eyes closed values were recorded in males in (NB) groups compared to (BT) groups. Lastly, males of (BT) groups had significantly higher eyes lost than (NB) groups. However, the (BT) groups had the lowest values of all aggressive pecking behavior traits compared to (NB) groups. Ultimately, feather pecking will lead to cannibalism, resulting in reduced production in the injured birds and eventually mortality. All aggressive pecking behavior traits significant affected by feed form and interaction ( $\mathrm{B} \mathrm{x}$ F) except head injuries traits. Birds fed mash were more attacked than birds fed pellet feed may be attributed to birds fed on pellets consumed their feed in a shorter time have less chance of being attacked (Savory and Hetherington, 1997). Generally, the injuries responses could be attributed to several reasons as aggressive behavior between males and the frequency copulation behavior of the males as well as force copulations for quail males with unreceptive females (Stephanie et al., 2011). Feather pecking and cannibalism are partly influenced by hormonal factors that can result in increases in these behaviors around the onset of lay (Keeling, 1995).

Table7. Effect of beak trimming and feed form on aggressive pecking behavior among males and mortality rate

\begin{tabular}{|c|c|c|c|c|c|c|c|}
\hline \multirow{2}{*}{$\begin{array}{c}\text { Traits } \rightarrow \\
\text { Treatment } \downarrow\end{array}$} & \multirow{2}{*}{$\begin{array}{c}\text { Head } \\
\text { injuries }\end{array}$} & \multirow{2}{*}{$\begin{array}{c}\text { Eyelid } \\
\text { injuries }\end{array}$} & \multirow{2}{*}{$\begin{array}{l}\text { Eye } \\
\text { closed }\end{array}$} & \multirow[t]{2}{*}{ Eye lost } & \multirow[t]{2}{*}{ Total } & \multicolumn{2}{|c|}{ Mortality (\%) } \\
\hline & & & & & & Males & Females \\
\hline \multicolumn{8}{|c|}{ Beak form (B) } \\
\hline Beak trimming (BT) & $1.08^{\mathrm{b}}$ & $2.05^{\mathrm{b}}$ & $2.00 \mathrm{~b}$ & $2.00^{\mathrm{b}}$ & $7.108^{b}$ & $1.25^{\mathrm{b}}$ & $8.31^{\mathrm{b}}$ \\
\hline Intact beak (NB) & $3.16^{\mathrm{a}}$ & $3.33^{\mathrm{a}}$ & $2.16^{\mathrm{a}}$ & $2.16^{\mathrm{a}}$ & $10.83^{\mathrm{a}}$ & $8.35^{\mathrm{a}}$ & $20.86^{\mathrm{a}}$ \\
\hline SEM & 0.261 & 0.16 & 0.02 & 0.02 & 0.28 & 0.64 & 0.36 \\
\hline Significance & $<.0001$ & $<.0001$ & $<.0001$ & $<.0001$ & $<.0001$ & $<.0001$ & $<.0001$ \\
\hline \multicolumn{8}{|c|}{ Feed form $(F)$} \\
\hline Mash (M) & $2.16^{\mathrm{a}}$ & $3.38^{\mathrm{a}}$ & $2.16^{\mathrm{a}}$ & $2.17^{\mathrm{a}}$ & $9.88^{\mathrm{a}}$ & $6.11^{\mathrm{a}}$ & $15.27^{\mathrm{a}}$ \\
\hline Pellets $(\mathrm{P})$ & $2.08^{\mathrm{a}}$ & $2.00^{\mathrm{b}}$ & $2.00^{\mathrm{b}}$ & $2.00^{\mathrm{b}}$ & $8.08^{\mathrm{b}}$ & $3.50^{\mathrm{b}}$ & $13.9^{\mathrm{b}}$ \\
\hline SEM & 0.26 & 0.15 & 0.02 & 0.019 & 0.28 & 0.64 & 0.36 \\
\hline Significance & 0.82 & $<.0001$ & $<.0001$ & $<.0001$ & 0.0004 & 0.01 & 0.01 \\
\hline \multicolumn{8}{|c|}{ Interaction $(B \times F)$} \\
\hline $\mathrm{BT} \times \mathrm{M}$ & 1.17 & $2.10^{\mathrm{b}}$ & $2.00^{\mathrm{b}}$ & $2.00^{\mathrm{b}}$ & $7.27^{\mathrm{c}}$ & $1.38^{\mathrm{c}}$ & $9.71^{\mathrm{c}}$ \\
\hline $\mathrm{BT} \times \mathrm{P}$ & 1.00 & $2.00^{\mathrm{b}}$ & $2.00^{\mathrm{b}}$ & $2.00^{\mathrm{b}}$ & $7.00^{\mathrm{c}}$ & $1.12^{\mathrm{c}}$ & $6.92^{\mathrm{d}}$ \\
\hline $\mathrm{NB} \times \mathrm{M}$ & 3.20 & $4.67^{\mathrm{a}}$ & $2.33^{\mathrm{a}}$ & $2.33^{\mathrm{a}}$ & $12.50^{\mathrm{a}}$ & $11.11^{\mathrm{a}}$ & $23.63^{\mathrm{a}}$ \\
\hline $\mathrm{NB} \times \mathrm{P}$ & 3.17 & $2.00^{\mathrm{b}}$ & $2.00^{\mathrm{b}}$ & $2.00^{\mathrm{b}}$ & $9.17^{\mathrm{b}}$ & $5.6^{\mathrm{b}}$ & $18.10^{\mathrm{b}}$ \\
\hline SEM & 0.37 & 0.22 & 0.03 & 0.03 & 0.39 & 0.91 & 0.51 \\
\hline Significance & 0.82 & $<.0001$ & $<.0001$ & $<.0001$ & 0.001 & 0.002 & $<.0001$ \\
\hline
\end{tabular}

Means within each column for each division with no common superscript letters are significantly different $(p \leq .05)$.

\section{Mortality rate:}

The males and females with (NB) groups had significantly higher total mortality rates compared to (BT) groups (Table 7). The higher mortality rate of (NB) birds could be attributed to the aggressive behavior among males occurs frequently, which leads to increased injuries responses in the different area, cannibalism and consequently increased mortality rate. These results agree with those of Oliveira, (2002), who found that the better performance as well as lower mortality rate for (BT) quails than those of quails submitted to poor (BT) practices. Similarly, Pizzolanteet al. (2007) recommended using the (BT) of quails especially at 14 or 21 days to improve the performance as well as reducing the mortality rate. In regard to feed forms, there was a positive effect of birds fed pellet feed on cannibalistic mortality in the trimmed groups and females' (NB) fed mash diet groups recorded higher significant mortality this is consistent with (Ghazi et al., 2012 and Ameret al., 2015) Table (7). Comparing beak form and feed physical form interaction, trimmed birds fed pellet feed showed lower cannibalistic mortality than the group of (NB) birds.

\section{Fertility and hatchability:}

The better percentage of fertility was recorded for the quails in (BT) groups compared to (NB) groups (Table 8). These results were consistent with those of Khalil et al. (2015), who found that the fertility and hatchability percentages were improved in (BT) Japanese quail group than those of the (NB) group. Moreover, there was insignificant difference between (NB) and (BT) groups in hatchability of fertile eggs percentage. Rodenburget al. (2004) proved that high incidence of feather pecking leads to more fearful and stressed hens in a flock and reduced production and fertility. The hatchability percentage was not affected by feed form, but fertility was significantly higher in birds fed pelleted diet vs. those fed mash diet. While, there was no affect of interaction of feed physical form $\times$ beak treatment on fertility and hatchability. 
Table 8. Effect of beak trimming (BT) and feed form on ovarian, fertility and hatchability of Japanese quails

\begin{tabular}{|c|c|c|c|c|c|c|}
\hline $\begin{array}{c}\text { Traits } \rightarrow \\
\text { Treatment } \downarrow\end{array}$ & $\begin{array}{c}\text { Ovary } \\
(\%)\end{array}$ & $\begin{array}{l}\text { Oviduct } \\
\text { length } \\
\text { (cm) }\end{array}$ & $\begin{array}{c}\text { Ovarian } \\
\text { yellow } \\
\text { follicle } \\
\text { number }\end{array}$ & $\begin{array}{c}\text { Ovarian } \\
\text { yellow } \\
\text { follicle } \\
(\%)\end{array}$ & $\begin{array}{c}\text { Fertility } \\
(\%)\end{array}$ & $\begin{array}{c}\text { Hatchability } \\
(\%)\end{array}$ \\
\hline \multicolumn{7}{|c|}{ Beak form (B) } \\
\hline Beak trimming (BT) & $3.09^{\mathrm{a}}$ & $38.188^{\mathrm{a}}$ & $3.62^{\mathrm{a}}$ & $2.91^{\mathrm{a}}$ & $86.97^{\mathrm{a}}$ & $69.77^{\mathrm{a}}$ \\
\hline Intact beak (NB) & $2.69^{\mathrm{b}}$ & $35.813^{\mathrm{a}}$ & $3.62^{\mathrm{a}}$ & $2.28^{\mathrm{b}}$ & $85.00^{\mathrm{b}}$ & $68.20^{\mathrm{a}}$ \\
\hline SEM & 0.12 & 0.99 & 0.242 & 0.131 & 0.700 & 1.31 \\
\hline Significance & 0.03 & 0.11 & 1.00 & 0.004 & 0.02 & 0.39 \\
\hline \multicolumn{7}{|c|}{ Feed form $(F)$} \\
\hline Mash (M) & $3.00^{\mathrm{a}}$ & $35.50^{b}$ & $3.68^{\mathrm{a}}$ & $2.78^{\mathrm{a}}$ & $83.01^{b}$ & $68.51^{\mathrm{a}}$ \\
\hline Pellets (P) & $2.77^{\mathrm{a}}$ & $38.50^{\mathrm{a}}$ & $3.56^{\mathrm{a}}$ & $2.40^{\mathrm{b}}$ & $88.97^{\mathrm{a}}$ & $69.46^{\mathrm{a}}$ \\
\hline SEM & 0.12 & 1.00 & 0.24 & 0.13 & 0.700 & 1.31 \\
\hline Significance & 0.17 & 0.05 & 0.72 & 0.05 & $<.0001$ & 0.61 \\
\hline \multicolumn{7}{|c|}{ Interaction $(\mathbf{B} \times \mathbf{F})$} \\
\hline $\mathrm{BT} \times \mathrm{M}$ & 3.09 & 34.75 & 3.63 & $82.18^{b}$ & 69.32 & 3.03 \\
\hline $\mathrm{BT} \times \mathrm{P}$ & 3.08 & 36.88 & 3.63 & $91.77^{\mathrm{a}}$ & 70.21 & 2.78 \\
\hline $\mathrm{NB} \times \mathrm{M}$ & 2.92 & 36.25 & 3.75 & $83.84^{\mathrm{b}}$ & 67.70 & 2.53 \\
\hline $\mathrm{NB} \times \mathrm{P}$ & 2.47 & 40.13 & 3.50 & $86.17^{\mathrm{b}}$ & 68.70 & 2.03 \\
\hline SEM & 0.17 & 1.40 & 0.34 & 0.83 & 1.15 & 0.18 \\
\hline Significance & 0.21 & 0.54 & 0.71 & 0.001 & 0.94 & 0.43 \\
\hline
\end{tabular}

Means within each column for each division with no common superscript letters are significantly different $(p \leq .05)$.

\section{Genital organs of female and male quails:}

In relation to females, results revealed that the (BT) and interactions between factors did not significantly affect ovarian yellow follicle number and length of oviduct but, significant differences were found among groups on ovary and ovarian yellow follicle percentages (Table 8). The higher relative ovary and ovarian yellow follicle percentages were recorded in females' (BT), while the lower value was recorded in (NB) groups. Moreover, there was no difference among experimental groups in testicular growth traits except in left testis width was significant wider than (NB) groups (Table 9). In respect of feed physical form and $\mathrm{B} \times \mathrm{F}$ interaction, no significant differences were found between the two feed forms in most genital organs of females and males. Relative percentages of ovary, oviduct, oviduct length and right testis width were significantly higher in pellets diet than mash diet. Moreover, (BT) males had the higher cloacal gland area than the males with (NB) groups.

\section{Testosterone concentration of male Japanese quails:}

Sex hormones are related to both sexual and aggressive behavior in a multifaceted way (Leshner, 1987). Likewise, Wingfieldet al. (1990) reported that the testosterone hormone of male quails plays an important role in the behavior of Japanese quails, which reached maximum level during the breeding season. The effect of (BT) on testosterone concentration of male is shown in Table (10). The results revealed that the testosterone concentrations as affected by beak trimming showed that (BT) groups was significantly lower than thoe of the quails with (NB) groups. These results perfectly consistent with(Khalil et al., 2015).The decrease in testosterone levels in the (BT) groups could be attributed to reducing aggressive behavior effects which leads to improving quail productivity. These results are in harmony with Knol and Egberink-Alink, (1989) who reported that the dominant or aggressive individuals tend to show higher plasma testosterone levels than submissive or less aggressive animals. Khalil et al. (2015) reported positive correlations between serum concentration of testosterone hormone and each of feather deterioration, head injuries, cloacae gland area, total mortality rates. Moreover, Hauet al. (2004) hypothesized that one mode of action of testosterone is to reduce pain sensitivity, possibly as a way of enhance aggressive behavior during aggressive facing this reduction in pain may promote the immediate and future willingness of males to engage in high intensity fights. Moreover, there were significantly higher testosterone levels in groups fed mash diet than those fed pelleted diet as reflecting effect of feed form. This result can be explained by the recorded higher aggressive behavior when quails were fed mash was higher than when fed pellets. In the same way, there was significant interaction effect of beak trimming $\times$ feed form on testosterone levels. 
Table 9: Effects of beak trimming and feed form on testes development and cloacae gland size ( $\left.\mathrm{mm}^{2}\right)$

\begin{tabular}{|c|c|c|c|c|c|c|}
\hline $\begin{array}{c}\text { Traits } \rightarrow \\
\text { Treatment } \downarrow\end{array}$ & $\begin{array}{c}\text { Right testis } \\
(\%)\end{array}$ & Left testis (\%) & $\begin{array}{c}\text { Testes } \\
(\%)\end{array}$ & $\begin{array}{l}\text { Right testis } \\
\text { length } \\
(\mathrm{cm})\end{array}$ & $\begin{array}{c}\text { Left testis } \\
\text { length }(\mathrm{cm})\end{array}$ & $\begin{array}{c}\text { Cloacal gland } \\
\left(\mathrm{mm}^{2}\right)\end{array}$ \\
\hline \multicolumn{7}{|c|}{ Beak form (B) } \\
\hline Beak trimming (BT) & $1.67^{\mathrm{a}}$ & $1.62^{\mathrm{a}}$ & $3.30^{\mathrm{a}}$ & $2.61^{\mathrm{a}}$ & $2.42^{\mathrm{a}}$ & $398.80^{\mathrm{a}}$ \\
\hline Intact beak (NB) & $1.61^{\mathrm{a}}$ & $1.48^{\mathrm{a}}$ & $3.10^{\mathrm{a}}$ & $2.58^{\mathrm{a}}$ & $2.43^{\mathrm{a}}$ & $331.20^{\mathrm{b}}$ \\
\hline SEM & 0.07 & 0.09 & 0.15 & 0.07 & 0.08 & 2.62 \\
\hline Significance & 0.59 & 0.33 & 0.38 & 0.74 & 0.93 & $<.0001$ \\
\hline \multicolumn{7}{|c|}{ Feed form $(F)$} \\
\hline Mash (M) & $1.59^{\mathrm{a}}$ & $1.51^{\mathrm{a}}$ & $3.11^{\mathrm{a}}$ & $2.60^{\mathrm{a}}$ & $2.37^{\mathrm{a}}$ & $365.83^{\mathrm{a}}$ \\
\hline Pellets (P) & $1.69^{\mathrm{a}}$ & $1.58^{\mathrm{a}}$ & $3.28^{\mathrm{a}}$ & $2.59^{\mathrm{a}}$ & $2.48^{\mathrm{a}}$ & $364.18^{\mathrm{a}}$ \\
\hline SEM & 0.15 & 0.22 & 0.24 & 0.07 & 0.08 & 2.62 \\
\hline Significance & 0.33 & 0.62 & 0.46 & 0.94 & 0.34 & 0.66 \\
\hline \multicolumn{7}{|c|}{ Interaction $(\mathrm{B} \times \mathbf{F})$} \\
\hline $\mathbf{B T} \times \mathbf{M}$ & 1.65 & 1.48 & 3.13 & 2.64 & 2.49 & 396.78 \\
\hline $\mathbf{B T} \times \mathbf{P}$ & 1.74 & 1.70 & 3.43 & 2.56 & 2.49 & 400.83 \\
\hline $\mathbf{N B} \times \mathbf{M}$ & 1.61 & 1.55 & 3.16 & 2.61 & 2.36 & 334.88 \\
\hline $\mathbf{N B} \times \mathbf{P}$ & 1.58 & 1.48 & 3.06 & 2.60 & 2.39 & 327.53 \\
\hline SEM & 0.22 & 0.31 & 0.34 & 0.10 & 0.11 & 3.71 \\
\hline Significance & 0.91 & 0.69 & 0.74 & 0.63 & 0.93 & 0.13 \\
\hline
\end{tabular}

Means within each column for each division with no common superscript letters are significantly different $(p \leq .05)$.

Table10. Effect of beak trimming and feed form on the hormonal profiles of Japanese quails

\begin{tabular}{|c|c|c|c|c|}
\hline \multirow{2}{*}{$\begin{array}{c}\text { Traits } \rightarrow \\
\text { Treatment } \downarrow\end{array}$} & \multirow{2}{*}{$\begin{array}{c}\text { Testosterone } \\
(\mathrm{ng} / \mathrm{mL})\end{array}$} & \multirow{2}{*}{$\begin{array}{c}\text { Progesterone } \\
\text { (ng/mL) }\end{array}$} & \multicolumn{2}{|c|}{ Corticosterone(ng/mL) } \\
\hline & & & Female & Male \\
\hline \multicolumn{5}{|c|}{ Effect of beak trimming $(T)$} \\
\hline Beak trimming (BT) & $2.65^{b}$ & $3.22^{\mathrm{a}}$ & $5.512^{\mathrm{b}}$ & $5.53^{b}$ \\
\hline Intact beak (NB) & $3.36^{\mathrm{a}}$ & $2.74^{\mathrm{b}}$ & $8.300^{\mathrm{a}}$ & $11.8^{\mathrm{a}}$ \\
\hline SEM & 0.04 & 0.07 & 0.25 & 0.32 \\
\hline Significance & $<.0001$ & 0.0001 & $<.0001$ & $<.0001$ \\
\hline \multicolumn{5}{|c|}{ Feed form $(F)$} \\
\hline Mash (M) & $3.15^{\mathrm{a}}$ & $2.92^{\mathrm{a}}$ & $6.812^{\mathrm{a}}$ & $8.52^{\mathrm{a}}$ \\
\hline Pellets (P) & $2.85^{\mathrm{b}}$ & $3.05^{\mathrm{a}}$ & $7.00^{\mathrm{a}}$ & $8.81^{\mathrm{a}}$ \\
\hline SEM & 0.04 & 0.07 & 0.25 & 0.33 \\
\hline Significance & $<.0001$ & 0.21 & 0.61 & 0.55 \\
\hline \multicolumn{5}{|c|}{ Interaction $(\mathrm{B} \times \mathrm{F})$} \\
\hline $\mathbf{B T} \times \mathbf{M}$ & $2.70^{\mathrm{b}}$ & 3.06 & 5.45 & 5.25 \\
\hline $\mathbf{B T} \times \mathbf{P}$ & $2.60^{\mathrm{b}}$ & 3.39 & 5.58 & 5.83 \\
\hline $\mathbf{N B} \times \mathbf{M}$ & $3.61^{\mathrm{a}}$ & 2.78 & 8.18 & 11.80 \\
\hline $\mathbf{N B} \times \mathbf{P}$ & $3.11^{\mathrm{a}}$ & 2.71 & 8.43 & 11.81 \\
\hline SEM & 0.06 & 0.10 & 0.35 & 0.46 \\
\hline Significance & 0.004 & 0.07 & 0.86 & 0.55 \\
\hline
\end{tabular}

Means within each column for each division with no common superscript letters are significantly different $(p \leq .05)$.

\section{Progesterone concentration of females Japanese quails:}

Females of (NB) groups had significantly lower progesterone concentration than (BT) groups (Table 10). Progesterone implanted in the hypothalamus of male doves suppressed courtship behavior and aggressiveness, demonstrating antagonism between progesterone and testosterone at a central level (Manning, 1981). Progesterone appeared to physiologically act as antagonists of androgens and behavioral effects of testosterone and progesterone on the brain are accomplished by the metabolites of these hormones (Knol and Egberink-Alink, 1989). Progesterone concentration was not affected by feed form when diets were fed in mash or pellet form. Moreover, there was insignificant effect of interaction of $\mathrm{B} \times \mathrm{F}$ groups on progesterone concentration.

\section{Plasma corticosterone concentration}

It was observed that the higher level of male plasma corticosterone was obtained in (NB) groups, while the lower value was obtained in (BT) groups (Table 10). However, females of (NB) had significantly higher plasma corticosterone level than the trimmed groups. Beak trimming may had reduced the stress of birds which resulted from aggressive pecking behavior and led to improved overall production and reproduction performance this improving may be attributed to increase of sexual hormones and decreased in anti-stress hormones. Females of (NB) groups had significantly higher corticosterone and significantly lower progesterone concentration. This means that they are under the influence of stresses. These results are in agreement with those of Khalil et al., (2005). This stress may be due to aggressive behavior of (NB) males towards females during mating. Corticosterone plays role of inhibition gonadal hormones synthesis, (LH), (FSH) and $(\mathrm{GnRH})$ this is believed to be the main pathway to inhibiting reproduction during stress time (Van Houtet al., 2010; Hassan et al., 2015 and Hanafy and Khalil 2015). From our experimental data, it was observed (NB) quails with higher corticosterone reduced ovary and ovarian yellow follicle percentage and decreased plasma progesterone concentration. These results are consistent with those of Petitte and Etches (1991). Also, (NB) quails with higher corticosterone reduced cloacal gland area, 
testosterone concentration, testes, fertilely percentages in male. Hanafy and Khalil (2015) also found negative correlation between corticosterone concentration and each of testes weights, cloacal gland area, foam production, semen characteristics and testosterone level in Japanese quail male when exposed to chronic artificial stress. Both feed form an interaction $\mathrm{B} \times \mathrm{F}$ had insignificant effects on corticosterone concentration.

\section{Hematological parameters:}

The blood profiles of female quail were shown in Tables 11 and 12 . The female quails WBC $\left(\times 10^{3}\right)$, PCV (\%), Hb (g/dl) and lymphocytes (\%) were significantly $(\mathrm{P} \leq 0.01)$ increased in the $(\mathrm{BT})$ groups, while the heterophils (\%) and monocytes (\%) were significantly $(\mathrm{P} \leq 0.01)$ decreased than those of the (NB) groups. The means of RBC, PCV, eosinophils and basophils were not affected by the (BT). Increase in $(\mathrm{Hb})$ may be accompanied by a rise in the $\mathrm{RBC}$ and $\mathrm{PCV} \%$ indicating absence of anemia (Waugh et al., 2001). The increased lymphocyte and decreased heterophils percentages could reflect the immunity response of (BT) quails. All hematology female values were not affected by feed form. These results agreed with the findings of ShahinReshadi, (2015) who reported that feed form (msh and pellets) had no significant effects on $\mathrm{H} / \mathrm{L}$ ratio and lymphoid organs weight. The beak trimming had insignificant interaction effect with feed form for all of the female hematology parameters studied except that RBC and $\mathrm{Hb}$ were significantly affected. Regarding the effect of (BT) on the hematological parameters on males, the WBC $\left(10^{3}\right)$, PCV (\%), $\mathrm{Hb}(\mathrm{g} / \mathrm{dl})$ and lymphocytes $(\%)$ in the (BT) groups were significantly increased than that of the (NB) groups, while, heterophils (\%), monocytes (\%), basophils (\%) and eosinophils (\%) were significantly decreased (Tables 13 and 14). The means of RBC $\left(\times 10^{6}\right)$ were not affected by the trimming of the beak. The significant improvement in the $\mathrm{Hb}, \mathrm{PCV}$ and $\mathrm{RBC}$ contents of the birds on (BT) groups could have been an indication of an increment in the oxygen carrying capacity of the animal's blood (Fasuyi andArire, 2015). The $\mathrm{H} / \mathrm{L}$ ratio is considered as a reliable indicator of long term stress condition in birds (Al-Murraniet al., 1997; Altanet al., 2003;Fathiet al. 2008 and AberraMelesse, 2011).The (NB) groups significantly $(\mathrm{P} \leq 0.01)$ reduces lymphocytes and increased the heterophills leading to an increased $\mathrm{H} / \mathrm{L}$ ratio than that of the $(\mathrm{NB})$ groups this increase it may be attributed to the negative effects of aggressive behavior that reduces feed intake, which thereby providing fewer nutrients for the proper development of lymphoid organs which were significantly reduced by aggression stressors (Bartlett and Smith, 2003).It could be stated that the birds with (NB) were more stressful than (BT) counterparts birds. The RBC, WBC, Hb, lymphocytes and basophiles percentages were insignificantly affected by feed form, but PCV, heteophils, eosinophils percentages and $\mathrm{H} / \mathrm{L}$ ratio were significantly higher in birds fed mash diet vs. those fed pelleted diet while monocytes was found to be less in birds fed mash than that in those fed pellet diet.Although mash diet resulted in increase of $\mathrm{H} / \mathrm{L}$ ratio compared with pellets groups, but $(\mathrm{B} \times \mathrm{F})$ interaction ineffective on $\mathrm{H} / \mathrm{L}$ ratio and there were significant difference among diet forms. Our results showed that form of feeds significantly affected blood hematological traits. Interaction $(\mathrm{B} \times \mathrm{F})$ of hematological parameters shown that RBC, WBC, lymphocytes and $\mathrm{H} / \mathrm{L}$ ratio didn't have any effect. However, there are several interactions between (BT) and form of feed on hematological traits (PCV, hemoglobin, lymphocyte, eosinophils, basophiles monocytes and heterophils). In general, the effects varied for the different evaluated criteria and it is not easy to have a general conclusion about this. However, it is clear that the effect of (BT) depends on type of diet (pellet vs. mash).

Table11. Effect of Beak trimming and feed form on the hematological parameters of female Japanese quails

\begin{tabular}{|c|c|c|c|c|}
\hline $\begin{array}{c}\text { Traits } \rightarrow \\
\text { Treatment } \downarrow\end{array}$ & RBCs $\left(\times 10^{6} / \mu \mathrm{l}\right)$ & WBCs $\left(\times 10^{3} / \mu \mathrm{l}\right)$ & PCV (\%) & Hemoglobin (g/dl) \\
\hline \multicolumn{5}{|c|}{ Beak form (B) } \\
\hline Beak trimming (BT) & $3.51^{\mathrm{a}}$ & $23.25^{\mathrm{a}}$ & $44.00^{\mathrm{a}}$ & $14.33^{\mathrm{a}}$ \\
\hline Intact beak (NB) & $3.26^{\mathrm{a}}$ & $17.67^{\mathrm{b}}$ & $41.33^{\mathrm{b}}$ & $12.17^{\mathrm{b}}$ \\
\hline SEM & 0.11 & 0.67 & 0.74 & 0.57 \\
\hline Significance & 0.14 & $<.0001$ & 0.02 & 0.02 \\
\hline \multicolumn{5}{|c|}{ Feed form $(F)$} \\
\hline $\operatorname{Mash}(\mathbf{M})$ & $3.26^{\mathrm{a}}$ & $19.83^{\mathrm{a}}$ & $43.33^{\mathrm{a}}$ & $13.67^{\mathrm{a}}$ \\
\hline Pellets (P) & $3.51^{\mathrm{a}}$ & $21.08^{\mathrm{a}}$ & $42.00^{\mathrm{a}}$ & $12.83^{\mathrm{a}}$ \\
\hline SEM & 0.11 & 0.67 & 0.74 & 0.57 \\
\hline Significance & 0.12 & 0.21 & 0.22 & 0.32 \\
\hline \multicolumn{5}{|c|}{ Interaction $(\mathbf{B} \times \mathbf{F})$} \\
\hline $\mathbf{B T} \times \mathbf{M}$ & 3.75 & 21.67 & 44.67 & 15.67 \\
\hline $\mathbf{B T} \times \mathbf{P}$ & 3.26 & 24.83 & 43.33 & 13.00 \\
\hline $\mathrm{NB} \times \mathrm{M}$ & 2.76 & 18.00 & 42.00 & 11.67 \\
\hline $\mathbf{N B} \times \mathbf{P}$ & 3.77 & 17.77 & 40.67 & 12.67 \\
\hline SEM & 0.16 & 0.95 & 1.04 & 0.81 \\
\hline Significance & 0.0003 & 0.06 & 1.00 & 0.04 \\
\hline
\end{tabular}

Means within each column for each division with no common superscript letters are significantly different $(p \leq .05)$. 
Table12. Effect of Beak trimming and feed form on the WBCs deferential of female Japanese quails

\begin{tabular}{|c|c|c|c|c|c|c|}
\hline $\begin{array}{c}\text { Traits } \rightarrow \\
\text { Treatment } \downarrow\end{array}$ & $\begin{array}{c}\text { Heterophils } \\
(\%)\end{array}$ & $\begin{array}{c}\text { Lymphocytes } \\
(\%)\end{array}$ & $\begin{array}{c}\text { Eosinophils } \\
(\%)\end{array}$ & $\begin{array}{c}\text { Monocytes } \\
\text { (\%) }\end{array}$ & $\begin{array}{c}\text { Basophils } \\
(\%)\end{array}$ & H/L ratio \\
\hline \multicolumn{7}{|c|}{ Beak form (B) } \\
\hline Beak trimming (BT) & $21.08^{\mathrm{b}}$ & $69.25^{\mathrm{a}}$ & $4.73^{\mathrm{a}}$ & $2.75^{b}$ & $2.17^{\mathrm{a}}$ & $0.30^{\mathrm{b}}$ \\
\hline Intact beak (NB) & $25.16^{\mathrm{a}}$ & $62.83^{\mathrm{b}}$ & $4.75^{\mathrm{a}}$ & $4.66^{\mathrm{a}}$ & $2.50^{\mathrm{a}}$ & $0.40^{\mathrm{a}}$ \\
\hline SEM & 0.50 & 0.66 & 0.64 & 0.60 & 0.16 & 0.01 \\
\hline Significance & $<.0001$ & $<.0001$ & 0.92 & 0.03 & 0.16 & $<.0001$ \\
\hline \multicolumn{7}{|c|}{ Feed form $(F)$} \\
\hline Mash (M) & $23.83^{\mathrm{a}}$ & $66.25^{\mathrm{a}}$ & $4.08^{\mathrm{a}}$ & $3.50^{\mathrm{a}}$ & $2.33^{\mathrm{a}}$ & $0.36^{\mathrm{a}}$ \\
\hline Pellets (P) & $22.42^{\mathrm{a}}$ & $65.83^{\mathrm{a}}$ & $5.50^{\mathrm{a}}$ & $3.91^{\mathrm{a}}$ & $2.33^{\mathrm{a}}$ & $0.34^{\mathrm{a}}$ \\
\hline SEM & 0.50 & 0.66 & 0.64 & 0.60 & 0.16 & 0.01 \\
\hline Significance & 0.06 & 0.72 & 0.10 & 0.61 & 1.00 & 0.18 \\
\hline \multicolumn{7}{|c|}{ Interaction $(\mathrm{B} \times \mathbf{F})$} \\
\hline $\mathbf{B T} \times \mathbf{M}$ & 22.00 & 70.00 & 3.67 & 2.33 & 0.31 & 2.00 \\
\hline $\mathbf{B T} \times \mathbf{P}$ & 20.17 & 71.67 & 5.00 & 2.33 & 0.28 & 2.33 \\
\hline $\mathbf{N B} \times \mathbf{M}$ & 25.67 & 64.33 & 3.67 & 3.67 & 0.40 & 2.67 \\
\hline $\mathbf{N B} \times \mathbf{P}$ & 24.67 & 63.33 & 5.00 & 4.67 & 0.39 & 2.33 \\
\hline SEM & 0.71 & 0.93 & 0.90 & 0.85 & 0.01 & 0.23 \\
\hline Significance & 0.56 & 0.83 & 0.92 & 0.75 & 0.16 & 0.64 \\
\hline
\end{tabular}

Means within each column for each division with no common superscript letters are significantly different $(p \leq .05)$.

Table13. Beak form (B) and feed form on the hematological parameters of males Japanese quails

\begin{tabular}{|c|c|c|c|c|c|}
\hline $\begin{array}{l}\text { Traits } \rightarrow \\
\text { Treatment } \downarrow\end{array}$ & $\begin{array}{c}\text { RBCs } \\
\left(\times 10^{6} / \mu \mathrm{l}\right)\end{array}$ & $\begin{array}{c}\text { WBCs } \\
\left(\times 10^{3} / \mu \mathrm{I}\right)\end{array}$ & PCV (\%) & $\begin{array}{l}\text { Hemoglobin } \\
\text { (g/dl) }\end{array}$ & $\begin{array}{c}\text { Heterophils } \\
(\%)\end{array}$ \\
\hline \multicolumn{6}{|c|}{ Beak form (B) } \\
\hline Beak trimming (BT) & $3.69^{\mathrm{a}}$ & $22.83^{\mathrm{a}}$ & $43.67^{\mathrm{a}}$ & $14.17^{\mathrm{a}}$ & $19.50^{\mathrm{b}}$ \\
\hline Intact beak (NB) & $3.42^{\mathrm{a}}$ & $19.08^{\mathrm{b}}$ & $41.83^{\mathrm{b}}$ & $12.83^{\mathrm{b}}$ & $25.17^{\mathrm{a}}$ \\
\hline SEM & 0.10 & 0.52 & 0.54 & 0.33 & 0.25 \\
\hline Significance & 0.09 & 0.0001 & 0.03 & 0.01 & $<.0001$ \\
\hline \multicolumn{6}{|c|}{ Feed form $(\mathrm{F})$} \\
\hline Mash (M) & $3.61^{\mathrm{a}}$ & $20.33^{\mathrm{a}}$ & $43.83^{\mathrm{a}}$ & $13.16^{\mathrm{a}}$ & $24.5^{\mathrm{a}}$ \\
\hline Pellets (P) & $3.49^{\mathrm{a}}$ & $21.58^{\mathrm{a}}$ & $41.66^{\mathrm{b}}$ & $13.83^{\mathrm{a}}$ & $20.17^{\mathrm{b}}$ \\
\hline SEM & 0.10 & 0.52 & 0.53 & 0.33 & 0.24 \\
\hline Significance & 0.42 & 0.11 & 0.01 & 0.17 & $<.0001$ \\
\hline \multicolumn{6}{|c|}{ Interaction $(B \times F)$} \\
\hline $\mathbf{B T} \times \mathbf{M}$ & 3.80 & 22.00 & 45.67 & 13.33 & 21.00 \\
\hline $\mathbf{B T} \times \mathbf{P}$ & 3.58 & 23.67 & 41.67 & 15.00 & 18.00 \\
\hline $\mathbf{N B} \times \mathbf{M}$ & 3.44 & 18.67 & 42.00 & 13.00 & 28.00 \\
\hline $\mathbf{N B} \times \mathbf{P}$ & 3.41 & 19.50 & 41.67 & 12.67 & 22.33 \\
\hline SEM & 0.14 & 0.74 & 0.76 & 0.47 & 0.35 \\
\hline Significance & 0.52 & 0.58 & 0.03 & 0.05 & 0.00 \\
\hline
\end{tabular}

Means within each column for each division with no common superscript letters are significantly different $(p \leq .05)$.

Table14. Beak form (B) and feed form on the WBCs deferential of males Japanese quails

\begin{tabular}{|c|c|c|c|c|c|}
\hline $\begin{array}{l}\text { Traits } \rightarrow \\
\text { Treatment } \downarrow\end{array}$ & $\begin{array}{c}\text { Lymphocytes } \\
\text { (\%) }\end{array}$ & $\begin{array}{c}\text { Eosinophils } \\
(\%)\end{array}$ & $\begin{array}{c}\text { Monocytes } \\
\text { (\%) }\end{array}$ & Basophils (\%) & $\mathrm{H} / \mathrm{L}$ ratio \\
\hline \multicolumn{6}{|c|}{ Beak form (B) } \\
\hline Beak trimming (BT) & $73.00^{\mathrm{a}}$ & $4.25^{b}$ & $2.08^{b}$ & $1.50^{\mathrm{b}}$ & $0.27^{b}$ \\
\hline Intact beak (NB) & $63.00^{\mathrm{b}}$ & $5.08^{\mathrm{a}}$ & $3.17^{\mathrm{a}}$ & $2.00^{\mathrm{a}}$ & $0.40^{\mathrm{a}}$ \\
\hline SEM & 0.79 & 0.23 & 0.27 & 0.16 & 0.01 \\
\hline Significance & $<.0001$ & 0.02 & 0.01 & 0.04 & $<.0001$ \\
\hline \multicolumn{6}{|c|}{ Feed form (F) } \\
\hline Mash (M) & $68.33^{\mathrm{a}}$ & $5.50^{\mathrm{a}}$ & $1.91^{\mathrm{b}}$ & $1.58^{\mathrm{a}}$ & $0.37^{\mathrm{a}}$ \\
\hline Pellets (P) & $67.66^{\mathrm{a}}$ & $3.83^{\mathrm{b}}$ & $3.33^{\mathrm{a}}$ & $1.92^{\mathrm{a}}$ & $0.30^{\mathrm{b}}$ \\
\hline SEM & 0.78 & 0.23 & 0.27 & 0.16 & 0.01 \\
\hline Significance & 0.56 & 0.0001 & 0.002 & 0.16 & $<.0001$ \\
\hline \multicolumn{6}{|c|}{ Interaction $(B \times F)$} \\
\hline $\mathbf{B T} \times \mathbf{M}$ & 73.67 & 3.00 & 1.50 & 0.29 & 1.17 \\
\hline $\mathbf{B T} \times \mathbf{P}$ & 72.33 & 5.50 & 2.67 & 0.25 & 1.83 \\
\hline $\mathbf{N B} \times \mathbf{M}$ & 63.00 & 4.67 & 2.33 & 0.45 & 2.00 \\
\hline $\mathbf{N B} \times \mathbf{P}$ & 63.00 & 5.50 & 4.00 & 0.36 & 2.00 \\
\hline SEM & 1.11 & 0.32 & 0.37 & 0.01 & 0.23 \\
\hline Significance & 0.56 & 0.02 & 0.01 & 0.012 & 0.16 \\
\hline
\end{tabular}

Means within each column for each division with no common superscript letters are significantly different $(p \leq .05)$. 


\section{CONCLUSIONS:}

The (BT) of birds had positive effects on physiological and productive characteristics of the laying quails, in order to reduce stress resulting from aggressive behavior, feather picking. Feed intake was not affected by the beak trimming, in both feed form (mash or pellets) but beak trimming improved feed efficiency by reducing the loss of feed.

\section{RECOMMENDATION}

Provide feed for beak trimming birds in the form of pellets to improve the productivity of laying quail and reduce stress.

\section{REFERENCES}

Adeola, O., 2006. Review of research in duck nutrient utilization. Poultry Science, 5: 201-218.

Al-Murrani, W. K., A. Kassab, H.Z. Al-Sam, A.M. Al-Athari, 1997.Heterophil/lymphocyte ratio as a selection criterion for heat resistance in domestic fowls. British Poultry Science, 38:159-163.

Altan, O., Pabuccuoglu, A., Altan, A., Konyalioglu, S., and H. Bayraktar, 2003.Effect of heat stress on oxidative stress, lipid peroxidation and some stress parameters in broilers. British Poultry Science, 44:545-550.

Amer, F. M., F.N. Soliman, M. Bahie El-Deen and Azza El-Sebai, 2015.Effect of diet forms and litter types on the productive traits of broiler (SASSO). Egyptian Poultry Science Journal, 35 (III): 719-734.

Amerah, A. M.,V. Ravindran, R.G. Lentle., and D.G. Thomas, 2007.Influence of Feed Particle Size on the Performance, Energy Utilization, Digestive Tract Development, and Digesta Parameters of Broiler Starters. Poultry Science, 86: 2615-2623.

Bartlett, J. R., and M.O. Smith, 2003. Effects of different levels of zinc on the performance and immune competence of broilers under heat stress. Poultry Science, 82: 1580- 1588.

Behnke, K.C., and R.S. Beyer, 2004. Effect of feed processing on broiler performance. Ph.D Dissertation, Kansas State University, Manhattan, USA.

Bourke, M., P.C. Glatz, J.L. Barnett, and K.L. Critchley, 2002. Beak trimming training manual.Edition 1, Publication no.02/092.Rural Industries Research and Development Corporation.

Bright, A., T.A. Jones, and M.S. Dawkins, 2006. A non-intrusive method of assessing plumage condition in commercial flocks of laying hens, Anim. Welfare, 15, 113-118.

Campos E.J., 1993.Comportamento efertilidade. Avicultura Ciênciae Tecnologia. 10:16-18.

Carter, T. C., 1975. The hen's egg: a rapid method for routine estimation of flock means shell thickness. British Poultry Science 16: 131-143.
Cerrate S., Z. Wang, C. Coto, F. Yan, P.W. Waldroup, 2009. Effect of pellet diameter in broiler starter diets on subsequent performance. J Appl Poult Res 18: 590-597.

Cheng, H., 2007. Morphopathological changes and pain in beak trimmed laying hens. World's Poultry Science Journal, 62: 41-52.

Cloutier, S., R.C. Newberry, C.T. Forster, K.M. Girsberger, 2000. Does pecking at inanimate stimuli predict cannibalistic behaviour in domestic fowl. Applied Animal Behaviour Science; 66:119-133.

CIVF, Compassion In World Farming, 2011: Controlling feather pecking and cannibalism in laying hens without beak trimming .http:// www.ciwf.org.uk/includes/docments/cm docs/2011/c/controlling feather pecking and cannibalism without beak trimming revised 030311.pdf

Dennis, R. L., H.W. Cheng, 2012. Effects of different infrared beak treatment protocols on chicken welfare and physiology.Poultry Science, 91:1499- 1505 .

Dennis, RL., Fahey AG. and HW. Cheng, 2009. Infrared beak treatment method compared with conventional hot-blade trimming in laying hens. Poultry Science, 88:38-43.

Dozier, W. A., K.C. Behnke, C.K. Gehring, and S.L. Branton, 2010. Effects of feed form on growth performance and processing yields of broiler chickens during a 42-day production period. J ApplPoult Res 19, 219-226.

Drew, P., C.R.J.S. Charles, B. Trevor, and L. John, 2004. Oxford Handbook of Clinical Haematology. Second Edition, Oxford University Press, USA.

Duncan, D. B., 1955. Multiple range and multiple F tests. Biometrics 11, 1-42.

EbruOnbaşılar E., E. Şahnur, Demirtaş, ZüleyhaKahraman, Ender Karademir, Sunay Demir, 2009. The influence of different beak trimming age on performance, $\mathrm{H}-\mathrm{L}$ ratio and antibody production to SRBC in laying hens. Trop Anim Health Prod, 41:221-227.

Farghly, M. F. A, 2012. Effect of mash, pellets, crumbles and wet feed on performance of Japanese quail during the summer. Egyptian Journal of Nutrition and Feeds, 15, 161-172.

Farghly, M.F.A., and D.E. Abou-Kassem, 2014. Impacts of feed color and form on growth performance of local turkey. Egyptian Journal of Nutrition and Feeds, 17: 537-547.

Farghly, M.F.A., O.S. Afifi, and H. H. M. Hassanien, 2014. Effect of feed form on broiler chicks performance. Paper presented at: The $7^{\text {th }}$ International Poultry Conference, 3-6 November, 2014, AinSukhna, Red Sea, Egypt, 49-57.

Fasuyi, A. O., and E. O. Arire, 2015. Particulating broiler finisher feeds into forms and diameters for nutritional and economic benefits (part 2). 
African Journal of Food Science. 9 (2), 76-83, February 2015.

Fathi, A.A., A.M. El-Shahed, M.A. Shoulkamy, H.A. Ibraheimand O.M. AbdelRahman, 2008. Response of Nile water phytoplankton to the toxicity Cobalt, Copper and Zinc. Res. J. Environ. Toxicol., 2: 67-76. DOI: 10.3923/rjet.2008.67.76.

FAWC, 2007. Opinion on Beak Trimming of Laying Hens.http://www.fawc.org.uk/pdf/enrichedcages. pdf.

Frikha, M., H. M. Safaa, M.P. Serrano, X. Arbe, and G.G. Mateos, 2009. Influence of the main cereal and feed form of the diet on performance and digestive tract traits of brown-egg.

Gerken, M., 1991. Antagonistic relationship between behavioural and production traits in poultry.Habilitation.Thesis, Bonn Uni, Science of Animal.

Ghazi, A.M. Z., A.A. Gameel, and M. Amer, 2012. A Comparative Effect of Mash and Pellet Feed on Broiler Performance and Ascites at High Altitude (Field Study). Global Veterinaria 9 (2): 154 -159.

Glatz, P., and M. Bourke, 2006. Beak Trimming Handbook for egg producers Best Practice for Minimising Cannibalism in Poultry. CSIRO Publishing, Collingwood, Victoria.

Glatz, P.C., 1987. Effects of beak trimming and restraint on heart rate, food intake, body weight and egg production on hens. British Poultry Science 28: 601-611.

Glatz, P.C., 2005. Poultry Welfare Issues: Beak Trimming Nottingham University Press, Nottingham, United Kingdom.

Greenwood, M.W., K.R. Cramer, P.M. Clark, K. C. Behnke, and R. S. Beyer, 2004. Influence of feed form on dietary lysine and energy intake and utilization of broilers from 14 to 30 days of age. Poultry Science, 3: 189-194.

Hanafy, A.M. and H.A. Khalil, 2015. Influence of Chronic Dexamethasone Administration on Reproductive Parameters and Semen Traits in Male of Japanese Quail. Asian J. Poult. Sci., 9: 223-232.

Hassan, A.K., A.Y. Mohamed, and M.M.H. Akrum, 2015. Behavioural Activities, Physiological Body Reactions, Hematological Parameters and Hormonal Profiles for bucks of White New Zealand and Baladi Red Exposed to Short Term of High Temperature. Asian J. Poult. Sci., 9: 191202.

Hassanien, H.H.M., and A.A.A. Abdel-Wareth, 2012. Influence of beak trimming and stocking density on performance and egg quality of laying hens in a tropical environment. Egyptian J. Anim. Prod. 49(1):45-51

Hau, M., O.A. Dominguez, and H.C. Evrard, 2004. Testosterone reduces responsiveness to nociceptive stimuli in a wild bird. Horm.Behav., 46: $165-170$.

Keeling, L. J., 1995. Feather pecking and cannibalism in layers.Poult.Internat. 6:46-50.
Khalil, H., A. Hanafy, A.M. Aml I Mekawy, and M.E. Mady, 2015. Effect of males pecking behavior on productive and physiological performance of Japanese quail and using some ways to reduce this behavior. Egyptian Poultry Science Journal, (35): 857-873.

Khalil, H.A., 2009. Productive and physiological responses of Japanese quail embryos to light regime during incubation period. Slovak J. Anim. Sci., 42: 79-86.

Khalil, H.A., A. Hanafy, M. Roshdy, and M.E. Mady, 2011.Effect of photoperiods and sex ratio on productive and reproductive performance of Japanese quail. Egyptian J. Anim. Prod. 48 : 295309.

Khalil, H.A., M.E. Mady, A.M. Hassanein and M. Gerken, 2012. Effects of different environmental temperatures during the rearing phase on behaviour traits in Japanese quail. Proceedings of the $3^{\text {rd }}$ Mediterranean Summit of WPSA and $6^{\text {th }}$ International Poultry, March 26-29, 2012, World Poultry Science Association, pp: 315-321.

Knol, B.W., and S.T. Egberink-Alink, 1989. Androgens, progestagens and agonistic behaviour: A review, Veterinary Quarterly, 11:2, 94-101.

Kuenzel, W.J., 2007. Neurobiological basis of sensory perception: Welfare implications of beak trimming. Poultry Science, 86:1273-1282.

Kul, S., I. Seker, 2004. Phenotypic correlation between some external and internal egg quality traits in the Japanese quail (Coturnixcoturnix japonica). Poultry Science, 3: 400-405.

Leandro, M.S.M, N.S. Vieira, and M.S. Matos, 2005. Desempenhoprodutivo de codornasjaponesas (Coturnixcoturnix japonica) submetidas a diferentesdensidades e tipos de debicagem.ActaScientiarum. Animal Sciences 2005; 27(1):129-135.

Leshner, A.I., 1978. An introduction to behavioral endocrinology.Oxford University Press, New York; 1978.

López, C.A.A., and N.C. Baião, 2004. Efeitos do tamanho da partícula e da forma física da raçãosobre o desempenho, rendimento de carcaça e peso dos órgãosdigestivos de frangos de corte. ArquivoBrasileiroMedicinaVeterinária Zootecnia, 56(2): 214-221.

Lv, M., L. Yan, Z. Wang, S. An, M. Wu, and Z. Lv, 2015. Effects of feed form and particle size on growth performance, carcass characteristics and digestive tract development of broilers. Animal Nutrition, 1, 252-256.

Ma1zama, D.G., and A.W. Adams, 1994. Effect of beak trimming, blade temperature and age at beak trimming on performance of two strains of egg layers, J. Appl. Poult. Res. 3:69-73.

Manning, A., 1981. An introduction to animal behavior 3.Edward Arno Ids Ltd., London.

Marchant-Forde, R.M., and H.W. Cheng, 2010. Different effects of infrared and one-half hot 
blade beak trimming on beak topography and growth. Poultry Science, 89: 2559-2564.

Martinec, V., W. Bessei, and K. Reiter, 2002. The influence of beak trimming on feeding activity and pecking of a bunch of feathers in 14 months old laying hens. Arch. Geflügelk., 66:193-200.

McDonald, D., 1987. Animal production, third edition; Longman, New York, U.S.A.

Melesse, A., S. Maak, R. Schmidt and G. von Lengerken, 2011. Effect of long-term heat stress on some performance traits and plasma enzyme activities in Naked-neck chickens and their $\mathrm{F}_{1}$ crosses with commercial layer breeds. Livestock Science, 141(2-3) : 227-231.

Mertens, K., J. Loffel, K. DE Baere, J. Zoons, J. De Baerdemaeker, and E. Decuypere, 2009. Layers in aviary system: Effects of beak trimming and alternative feed formulation on technical results and egg quality. Journal Applied Poultry Research, 18(1) :90-102.

Mingbin, L., Y. Lei, W. Zhengguo, A. Sha, W. Miaomiao, and L. Zunzhou, 2015. Effects of feed form and feed particle size on growth performance, carcass characteristics and digestive tract development of broilers. Animal Nutrition, 1: 252-256.

Moran, E.T., JR., 1990. Effect of pellet quality on the performance of meat birds.Poult.Abst., 16: 2875.

Moritz, J.S., A.S. Parsons, N.P. Buchanan, W.B. Calvalcanti, K.R. Cramer, and R.S. Beyer, 2005. Effect of Gelatinizing Dietary Starch Through Feed Processing on Zero- to Three-Week Broiler Performance and Metabolism. J ApplPoult Res, 14: $47-54$

Murakami, A.E., L.M.G. Souza, M.I. Sakamoto and J.I.M. Fernandes, 2008. Using Processed Feeds For Laying Quails (Coturnixcoturnix japonica). ISSN 1516-635X Oct - Dec 2008 / v.10 / n.4 / $205-208$.

North, M.O., and D.D. Bell, 1990. Commercial Chicken Production Manual. Chapman \& Hall: New York, London. pp. 472-473.

NRC, 1994. Nutrient requirements of poultry. $9^{\text {th }}$ rev. version, National Research Council, Washington, DC, USA

Oliveira, B.L., 2002. Manejoracionalprodutividad das codornas. In: SimposioInternacional de Coturnicultura, Lavras. MG. Ansis. Lavras: p.7795.

Petitte, J.N. and R.J. Etches, 1991. Daily infusion of corticosterone and reproductive function in the domestic hen (Gallus domesticus). Gen. Comp. Endocrinol., 3: 397-405.

Pizzolante, C.C., E.A. Garcia, E.S.P.B. Saldanha, C. Langan, A.B.G. Faitarone, H.B.A. Souza, and K. Pelicia, 2007. Beak trimming methods and their effect on the performance and egg quality of Japanese quails (Coturnix japonica) during lay. Braz J Poult. Sci. 2007;6:17-21.

Preston, C.M., K.J. McCracken, A. McAllister, 2000. Effect of diet form and enzyme supplementation on growth, efficiency and energy utilisation of wheat-based diets for broilers. British Poultry Science, 41: 324-331.

Rajput, N., M. Naeem, S. Ali, A.M. Shah, H. Rizwana, A.R. Shah, A. R. Jehejo, 2016. Effect of Various Forms of Feed on Growth Performance of Japanese Quail. Sindh Univ. Res. Jour. (Sci. Ser.) Vol. 48(4) 879-882 (2016).

Rodenburg, T.B., A.J. Buitenhuis, B.K.A. Ask, 2004. Uitdehaag, P. Koene, J. J.v.d. Poel, J.A. M.v. Arendonk, and H. Bovenhuis. Genetic and phenotypic correlations between feather pecking and open-field response in laying hens at two different ages. Behav. Genet. 34:407-415.

SAS, 2009. SAS user's guide, statistics, $9.2^{\text {th }}$ edn. Cary, NC: SAS Institute Inc.

Savory, C. J., and J. D. Hetherington 1997. Effects of plastic anti-pecking devices on food intake and behavior of laying hens fed on pellets or mash. British Poultry Science, 38: 125-131.

Scott, T. A., 2002. Evaluation of lighting programs, diet density, and short-term use of mash as compared to crumbled starter to reduce incidence of sudden death syndrome in broiler chicks to 35 days of age. Canadian Journal of Animal Science, vol. 82, (3) : 375-383.

Shahin, Reshadi-Nejad, Seyed Ali Tabeidian and Majid Toghyani, 2015. The Effect of Diet type (Mash, Pellets, Extruded and Crumble) on some Immune Responses Broiler Chicken. Biological Forum - An International Journal 7 (1): 901-904 (2015)

Shunmura, T., Y. Eguchi, K. Uetake, and T. Tanaka, 2006. Effects of light intensity and beak trimming on preventing aggression in laying hens. Anim. Sci, 77: 447-453.

Souza, PA., R.R.S. Faleiros, H.B.A. Souza, Efeitossobre a qualidade dos ovos.Avicultura Industrial 1984; 893:24-7.

Steel, R. G. D., and J. H. Torrie, 1980. Principles and Procedures of Statistics.A Biometrical Approach. $2^{\text {nd }}$ ed.

Stephanie, M.C., C.M. Horan, P.A. Johnson, and E. Adkins-Regan, 2011. Copulatory behaviors and body condition predict post-mating female hormone concentrations, fertilization success, and primary sex ratios in Japanese quail. Horm.Behav., 59: 556-564.

Tanaka, T., H. Mizuta, T. Yoshimoto, K. Mimura, T. Ito, 1983. Effects of debeaking on the feeding behaviour of laying hens. Japanese Journal of Livestock Management 18, 88-94. (In Japanese with English summary).

Tauson, R., J. Kjaer, G. Maria, R. Cepero, and K.E. Holm, 2005. Applied sco-ring of integument and health in laying hens. Anim. Sci. 23: 153-159.

Tauson, R.,T., Ambrosen, and K. Elwinger, 1984. Evaluation of procedures for scoring the integument of laying hens-Independent scoring of plumage condition.Acta Agric. Scand. 34: 400-408.

Van Hout, A.J.M., M. Eens, V.M. Darras, and R. Pinxten, 2010. General and plasma testosterone 
in a free-ranging male songbird: potential site of action and mechanism. Gen. Comp.

Van Krimpen, M.M., R.P. Kwakkel, B.F.J. Reuvekamp, C. M. C., Van Der Peet-Schwering, L. A. Den Hartog, and M. W. A. Verstegen, 2005. Impact of feeding management on feather pecking in laying hens. Poultry Science, 61:663685.

Walser, P., and H.P. Pfirter, 2001. Feed structure influences behaviour of laying hens. In Proceedings of the 6th European symposium on poultry welfare. (eds. H. Oester and C. Wyss).
Waugh, A., and A. Grant, 2001. Anatomy and Physiology in Health and Illness. 9th ed. Churchill Livingstone, an Imprint of Elsevier Science Limited, pp: 59-70.

Wingfield, J.C., R.E. Hegner, A.M. Dufty, and G.F. Ball, 1990. The challenge hypothesis: theoretical implications for patterns of testosterone secretion, mating systems, and breeding strategies. Am Nat 1990; 136: 829-846.

\section{التأثيرات الفسيولوجية والإنتاجية لقص المنقار وشكل العلف في السمان الياباني}

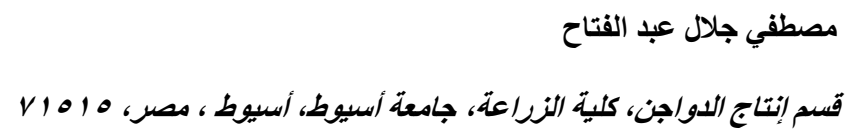

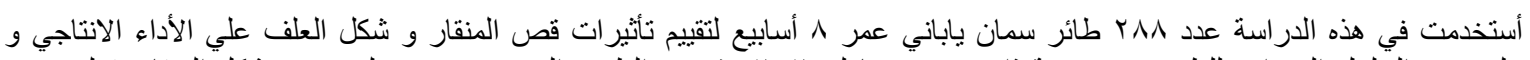

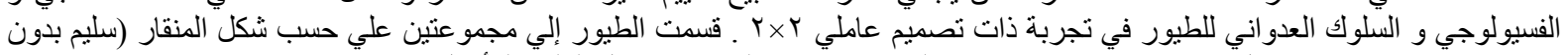

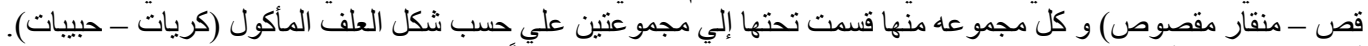

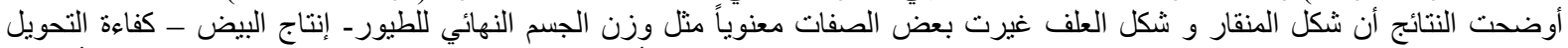

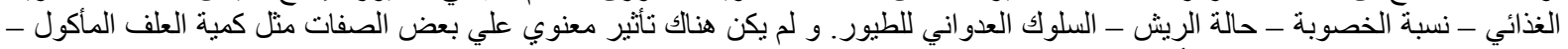

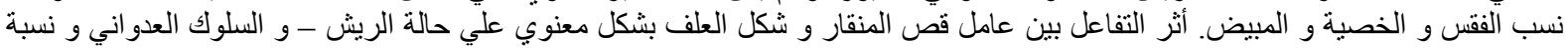
النفوق و بعض صفات الدام.

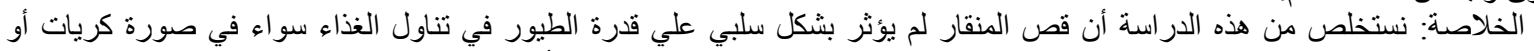

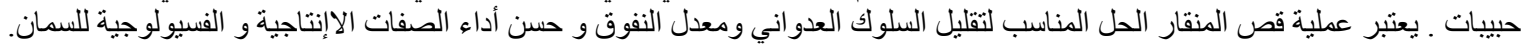

